\title{
The Aspects of National Branding: Conceptual and Theoretical Framework
}

\author{
Sršen Andreja \\ Assistant Professor University of Zagreb, \\ Croatian Studies. Sociology Department
}

\section{Abstract}

The concept of countries as brands has been increasingly recognized in the post-modern global world. The terms "national brand" or "country brand" define a symbolic construct, which emphasizes the attractive, unique and sustainable qualities of a nation. This paper argues that the national brand and its competitiveness, based on the new approaches of nation branding using sociological and economic theories and concepts, can establish and communicate a specific image of national identity. This paper presents some empirical findings of a study that investigate Croatian national brand. Nation branding might be obtained by a sustained dialog between government, decision makers, business, cultural and civil community, leaders, and individuals in the society. A country brand, therefore, consists of an identity and image, as a system of signs and codes, where nation branding applies widely used marketing concepts for promoting the country's image and attractiveness. Finally, the paper argues that "national brand" or "country brand"is not just a function individually performed by governments or companies, but an integrated and concerted effort on behalf of all interested stakeholders.

Keywords: country brand, national brand, image, marketing, Croatia.

\section{Introduction}

Every nation has a certain image, be it favorable or unfavorable. These perceptions determine the development of the country, most commonly with respect to foreign direct investments, national sport's achievements or tourism. A brand takes the form of a symbolic construct although this definition does not emphasis enough the abstract dimensions of the brand. It is clear that a brand is differentiated from the simple idea of a product through a set of values that go beyond mere functional performance. ${ }^{1}$ Combining both, producers and consumers, branding generally brings advantages to both and customers are always a fundamental entity in branding decisions, either at the starting point, or as final arbiters. ${ }^{2}$ Developing a sustainable and successful brand is a complex image management issue. The paper also considers developing a debate on the challenges encountered by the "national identity concept" in different social fields, and try to incorporate "branding strategy type" in a larger multidisciplinary perspective of social identity, considered by the fields of sociology and marketing. The scientific disciplines as sociology, psychology, economy tackle elements regarding the image. The study of the image takes place in a fragmented way, within several independent scientific fields, each dealing with a specific category of the image according to the discipline within which the notion of "image" is addressed. The term "image" has different connotations, to suit the context in which it is used. Nowadays the importance of country image and country brand in the market, but also in the public diplomacy is growing rapidly. Nation branding is also a part of public diplomacy and is considered an instrument although nation branding and public diplomacy have different goals, strategies According to Szondi G. there are five different views that can be identified concerning these relationship. ${ }^{3}$ The first one relies on the concept that these two areas do not share any common grounds. The second one, which is the most popular amongst scholars is that public diplomacy presents some advantages in the direction of making public diplomacy more strategic, as such, is a part of nation branding. According to a third approach nation branding is, not only a part of public diplomacy, but an instrument of public diplomacy where nation branding could be used in international relations, as well as, in public diplomacy. In the fourth approach, public diplomacy and nation branding share some common grounds with some similarities between them. The final option argues that both nation branding and public diplomacy have a common goal of

\footnotetext{
1 Ind, N., (1997), The Corporate Brand, Macmillan Press, London.

2 Kapferer, J. N., (2001), (Re)inventing the brand: can top brands survive the new market realities?, Kogan Page, London.

3 Szondi, G., (2008), 'Public Diplomacy and Nation Branding: Conceptual Similarities and Differences". Discussion papers in Diplomacy, Netherlands Institute of International Relations 'Clingendael'.
} 
creating positive nation image. Nation branding has a more European root and appeal of clear British dominance by Simon Anholt and Wally Olins, the two 'gurus' and strong advocates of nation branding who have largely contributed to its evolution and practice, whereas public diplomacy was paved by American scholars and practitioners, and it was described as a 'peculiarly American aberration'.'

\section{Methodology - Brand Perception and Rankings}

The research methodology is mainly summarized to all appropriate methods and techniques used for collecting and processing empirical data and information, respectively to observing, categorizing and analyzing data so that it can be founded the addressed theoretical elements. Nation Brands Index 2 takes the pulse of international public perception by polling individuals in 50 countries about their views of a target country's structure of governance, exports, tourism, people, culture, heritage, investment, and immigration. It measures the power and quality of each country's 'brand image' by combining the following six dimensions:

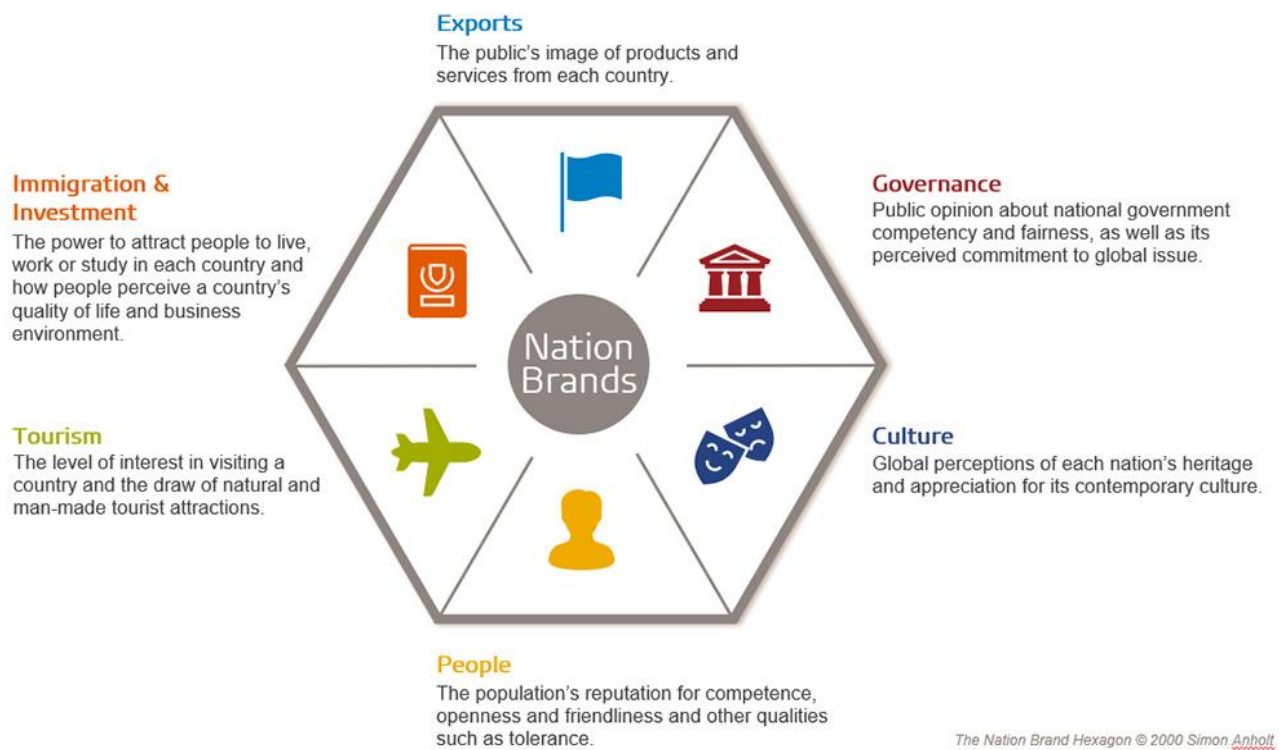

Source: The Anholt-GfK Nation Brands IndexSM (NBISM)

Simon Anholt writes in a report (2007) that "every responsible government in the global age, is duty bound to take steps in the management of their nation's reputation, since the only sort of government that can afford to ignore the impact of its national reputation is one which has no interest in participating in the global community, and no desire for its economy, its culture or its citizens to benefit from the rich influences and opportunities that the rest of the world offers them..".

\footnotetext{
1 Laqueur, W. (1994) 'Save Public Diplomacy - Broadcasting America's Message Matters' Foreign Affairs 73(5): 19-24., quoted in: Vaxevanidou, M., (2017), Nation Rebranding in A Period of Crisis and the Role of Public Diplomacy: The Case Study of Greece. Journal of Media Critiques, Vol. 3, No. 11., p. 59.

2 The Anholt-GfK Nation Brands IndexSM (NBISM). < https://nation-brands.gfk.com/ >

${ }^{3}$ Anholt, S. (2007). Competitive identity: The new brand management for nations, cities, and regions. New York, NY: Palgrave Macmillan, p. 3.
} 
Because of the continued increase of the importance of national branding numerous institutions around the world are trying to "measure" the strength of individual countries as brands. Such rankings can be used for additional promotion of individual countries as they are mostly based on extensive public opinion surveys.

\section{Country image and country brand}

Nowadays, there are many differences between country image and country brand. According to Kunczik, "the image of a nation is formed by a highly complex communication process involving diverse information sources. [...] Those who create the most powerful images are international TV and radio, newspapers and magazines, cultural exchange programs, commercials, books, news services. Add to this education and travelling, i.e. the degree of personal experience related to certain foreign cultures that also has an important role in building an image". ${ }^{1}$ Brands have been understood as crucial devices for contemporary capitalism, in so far as they mediate and organize global flows of production and allow for the subsumption of the cognitive labor of consumers in mediated societies. Generally, we could agree that each country has its own image. Interpreting existing definitions in literature on the image of a country/nation, it is easy to see that some of these terms give a small, custom meaning, while others cover a wider area, describing the image as an umbrella concept. ${ }^{2}$

Figure 1 - Country image definitions ${ }^{3}$

\begin{tabular}{|l|l|}
\hline Author(s) & Definition \\
\hline Bannister - Saunders (1978, p. 562) & $\begin{array}{l}\text { Country image is an overall image that is constituted by variables like } \\
\text { peculiar products, economic and political development, historical events } \\
\text { and relationships, traditions, level of industrialization and of technological } \\
\text { development. }\end{array}$ \\
\hline Martin - Eroglu (1993, p. 193) & $\begin{array}{l}\text { Country image is the set of normative inferred and informational beliefs of } \\
\text { individuals on a country. }\end{array}$ \\
\hline Kotler et.al. (1993, p. 141) & $\begin{array}{l}\text { Country image is the sum of people's beliefs, ideas and impressions } \\
\text { about a certain country. }\end{array}$ \\
\hline Szeles (1998, p. 96) & $\begin{array}{l}\text { Country image is an internal and external framework of the opinions and } \\
\text { beliefs on a people, nation and country and the simultaneously objective } \\
\text { and subjective psychological contents of eterogeneous and generalized } \\
\text { value judgment thereof. }\end{array}$ \\
\hline Verlegh - Steenkamp (1999, p. 525) & $\begin{array}{l}\text { A mental interpretation of a country's inhabitants, products, culture and } \\
\text { national symbols. }\end{array}$ \\
\hline Brijs et.al. (2011, p. 1260) & $\begin{array}{l}\text { Country image represents all that a consumer attaches to a country and } \\
\text { its inhabitants (and not to its products). }\end{array}$ \\
\hline
\end{tabular}

Relating to the literature in the field of marketing, an image is presented in a number of the following brand image definitions:

\footnotetext{
${ }^{1}$ Kunczik M., (1997), Images of nations and international public relations, New Jersey: Lawrence Erlbaum Associate, Publishers; p. 41.

2 Cotirlea, D. A., ( 2015), Country image vs. Country brand: differences and similarities, ECOFORUM, Vol. 4, Special Issue 1; p. 166.

${ }^{3}$ Cotirlea, D. A., ( 2015), Country image vs. Country brand: differences and similarities, ECOFORUM, Vol. 4, Special Issue 1; p. 167.

4 Išoraite', M., ( 2018) Brand Image Development, ECOFORUM, Vol. 7, Issue 1(14), p. 1-2.
} 
Figure 2 - Country image definitions in the field of marketing ${ }^{1}$

\begin{tabular}{|c|c|}
\hline Author & Definition \\
\hline $\begin{array}{l}\text { Malik, Naeem , } \\
\text { Munawar (2012) }\end{array}$ & $\begin{array}{l}\text { Brand image is an integral component of brand equity as it conveys the } \\
\text { worth } \\
\text { of the brand to the consumers. }\end{array}$ \\
\hline Arora, Stoner (2009) & $\begin{array}{l}\text { Brand image represents the emotional aspects that identify the brand of a } \\
\text { company or its products, and has a powerful impact on consumer buying } \\
\text { behavior. }\end{array}$ \\
\hline Aaker (1992) & $\begin{array}{l}\text { Brand image as a "set of associations, usually organized in some } \\
\text { meaningful } \\
\text { way". }\end{array}$ \\
\hline Keller (1993) & $\begin{array}{l}\text { Brand image as a"perceptions about a brand as reflected by the brand } \\
\text { associations held in consumer memory". }\end{array}$ \\
\hline Aaker (1997) & $\begin{array}{l}\text { While Brand image represents all the emotional aspects that identify a } \\
\text { brand, brand personality represents human characteristics that have been } \\
\text { given to a brand. }\end{array}$ \\
\hline Kalieva (2015) & $\begin{array}{l}\text { "Brand" and "image"--are single, but not identical concepts. "Image" in } \\
\text { relation to "brand" is perceived by the target audience as "a generalized } \\
\text { portrait" of the branded object. The image-generating qualities are planned } \\
\text { actions of the branded object, demonstrating them we can form public } \\
\text { opinion. }\end{array}$ \\
\hline $\begin{array}{l}\text { Lee, James, Kim } \\
\text { (2014) }\end{array}$ & $\begin{array}{l}\text { Brand image forms the basis for making better strategic marketing decisions } \\
\text { about targeting specific market segments and positioning a product. }\end{array}$ \\
\hline Herzog (1963) & $\begin{array}{l}\text { Brand image is the sum total of impressions the consumer receives from } \\
\text { many sources. }\end{array}$ \\
\hline Dichter (1985) & $\begin{array}{l}\text { Brand image is the configuration of the whole field of the object, the } \\
\text { advertising, and more important, the customer's disposition and the } \\
\text { attitudinal screen through which he observes. }\end{array}$ \\
\hline Chien-Hsiung (2011) & $\begin{array}{l}\text { Brand image is indispensable for marketing where customers infer the } \\
\text { quality of products by the brand image and are further stirred up the } \\
\text { behavior of purchasing. }\end{array}$ \\
\hline $\begin{array}{l}\text { Ballantyne, Warren, } \\
\text { Nobbs (2005) }\end{array}$ & $\begin{array}{l}\text { Brand image as the material property associated with the brand, such as the } \\
\text { product name and the packing, which could make profits or sense for } \\
\text { customers and help or increase describing the characteristics. }\end{array}$ \\
\hline Dobni (1990) & Brand image as the brand concept that customers held. \\
\hline Robert , Patrick (2009) & $\begin{array}{l}\text { Most brand image was subjectively perceived image, which was interpreted } \\
\text { from the rationality or the sensitivity of customers. }\end{array}$ \\
\hline Magid, Cox (2006) & $\begin{array}{l}\text { Magid and Cox (2006) considered brand image as a set of assets and } \\
\text { liabilities linked with brand name and sign that the assets and liabilities } \\
\text { increased or reduced the value by the enterprise providing products or } \\
\text { services for customers. Brand image included the customer responses to } \\
\text { the brand name, } \\
\text { sign or impression, and also represented the symbol of the product quality. }\end{array}$ \\
\hline
\end{tabular}

1 Ibidem. 


\begin{tabular}{|l|l|}
\hline Porter (1997) & $\begin{array}{l}\text { Porter (1997) measured brand image from two dimensions, namely the } \\
\text { symbol and the function. With adjectives to measure the two dimensions, } \\
\text { the measuring items mainly focused on the utility of the brand regarding the } \\
\text { function, while words like symbolic, reputable, status symbol, and } \\
\text { identifiable } \\
\text { were contained in terms of symbolic image. Positive and negative } \\
\text { adjectives, such as simple, romantic, successful, common, ordinary, } \\
\text { obedient, calm, and elegant, were utilized to describe the characteristics of } \\
\text { users. }\end{array}$ \\
\hline Schiffman, Kanuk (2010) & $\begin{array}{l}\text { A positive brand image will enable marketing program can be liked and be } \\
\text { able to produce unique associations to the brand that always exist in } \\
\text { customer retention. }\end{array}$ \\
\hline Pujadi (2010) & $\begin{array}{l}\text { Brand image is often referenced in the psychological aspects of the image } \\
\text { or impression that is built into the subconscious of consumers through the } \\
\text { expectations and experience of taking the brand over a product or service, } \\
\text { thus forming a positive brand image is becoming increasingly important to } \\
\text { be owned by the company. }\end{array}$ \\
\hline $\begin{array}{l}\text { Hawkins, Best, \& } \\
\text { Coney, (2004). }\end{array}$ & $\begin{array}{l}\text { Brand image is also regarded as a description of the offer of the company } \\
\text { which includes the symbolic meaning associated customers through specific } \\
\text { attributes of the products or services. }\end{array}$ \\
\hline Winarso (2012) & $\begin{array}{l}\text { Brand image is a perception in the mind of the customers a good impression } \\
\text { of a brand. }\end{array}$ \\
\hline
\end{tabular}

The above brand image definitions show that branding, consequently is not only the consequence of a center of action "the seller" which add the layer of the brand to its product, but can also be understood as the realization of an assemble of distributed actors in the form of a public. It is important to notice that, despite its original relation with markets, brand image do not pertain to firms alone. Moreover, the notion of image brand does not only refer to the "mark" or the "logo" through which a firm, a political party, or a state can be visually recognized. Image brands represent a shared imaginary, culture codes and sense of belonging.

\section{Beyond Branding and Identity}

Nation branding' incorporates political, economic, cultural, sociological and historical approaches. Nation branding can also be defined as the strategic self-presentation of a country. According to this, creating reputational capital through economic, political and social interest, nation branding can be examined as a part of public diplomacy and is considered an instrument of public diplomacy. In this case, the role of governments is crucial in influencing public perception, especially in protecting the country's reputation, correcting poor or negative images and stereotypes public, wherefore diplomacy becomes the vital function. According to Ham P., the modern world of geopolitics is being replaced by the postmodern world of images and influences. ${ }^{1}$ Therefore the traditional diplomacy is disappearing and identity politics is becoming the main activity of politicians and states. There is a widespread consensus that if national brand can reflects the marketing efforts of brand management it needs to correspond to brand identity, branding strategies and brand management. These invisible and unwritten concepts of the business are undertaken by public diplomacy. In this context according to Olins W., whose book Trading Identities: Why countries and companies are taking on each other's roles established a linkage between state branding and companies, countries should act like companies. According to Olins W., countries have always branded themselves and it is just a new term for image management as the strategic self-presentation of a country with the aim of

\footnotetext{
${ }^{1}$ Ham, P. van, (2002) 'Branding Territory: Inside the Wonderful Worlds of PR and IR Theory', Millennium 31(2): $249-269$.
} 
creating reputational capital through economic, political and social. Therefore, there are six basic stages in building country image brand: 1

Forming a work group with representatives of government, industry, the arts, education and media;

Establishing how the nation is perceived both internally and externally by means of qualitative and quantitative research tools;

Establishing the strengths and weaknesses of the country, and compare them with other similar research data, whether they originate within the country or outside;

Creation of a central idea, powerful and simple, on which the strategy is based and which captures the unique qualities of the nation;

Message coordination, especially with respect to tourism, inward investment and exports;

Formation of a liaison system, within the working party, to implement the programme and encourage supportive actions from appropriate organizations in commerce, industry, arts, media and so on. ${ }^{2}$

According to Anthony Smith the concept of national identity embodies a historic territory or homeland, common myths and historical memories, a common or mass culture and duties for all members, a common economy and increased territorial mobility for its members. ${ }^{3}$ Benedict Anderson argues that the nation is to be imagined as a unique entity in terms of time and space and his concept of nation is understood in terms of "imagined community". ${ }^{4}$ Within the imagined national community, new narratives can change people's perceptions of what constitutes their national identity Nowadays, the mythical edifice of national identity described by Anderson or Smith starts to be challenged by the emerging of other multiple complex structures and consequently, the idea of national identity, which represents the content of the branding nation strategy, has to be rigorously interrogated. Therefore, the concept of nation branding has an extended tradition in the economic field. That means that nation branding becomes a more recognized and a more familiar concept and it is important to note that the principles and basics for nation branding are not too distant from those applied to traditional brands.

\section{World Cup 2018 - How Football can Brend the Entire Nation}

Sport is one of the most profitable industries in the world. One of the specifics of sports is the fact that in sport, „small countries", as Croatia is, can often be greater than the "large countries". Promotion through sport is considered to be the purest and most positive type of promotion and nation branding, because all competitors in sports events have an equal chance to succeed.

Croatia is primarly recognised as a tourism country. It is recognised as an attractive and safe European destination, as one of the ecologically most preserved countries of the EU, with a rich cultural and historical heritage.

Despite the fact that Croatia as a country is associated with tourism, culture and heritage, which give credit to Croatia as a brand name, Croatia was the ultimate surprise of the FIFA World Cup 2018 and showed how football can brand the entire nation. Croatia is so small people use Google to find out that we can talk about lack of brand recognizability. Nobody expected that a small nation of 4 million people will be taking home the silver medal.

During the FIFA World Cup 2018 agency Mediatoolkit measured how much exposure Croatia as a country got thanks to this sporting event and the corresponding impact it had on the country's recognizability. ${ }^{5}$ When Croatia moved past Denmark to face off Russia in the quarterfinal, Croatia went from having approximately 100 daily mentions to more than 150,000 mentions after the match. Sudden media interest started with Croatia winning against Russia.

\footnotetext{
1 Olins, W., (1999), "Trading Identities: Why Countries and Companies are Taking on Each Others Roles?", The Foreign Policy Center, London;

2 Đorđević, Bojan (2009). Corporate Strategic Branding: How Country and Corporate Brands Come Together; Economic Annals, No.177; p. 11.

${ }^{3}$ Smith, Anthony D., National identity" 1991, Penguin books, Ch. 2.

${ }^{4}$ Anderson, Benedict, Imagined communities: reflections on the origin and spread of nationalism, 1991, Verso, London.

${ }^{5}$ Mediatoolkit. https://www.mediatoolkit.com/blog/croatia-world-cup-media-analysis/
} 
Figure 3 - media interest: Croatia winning against Russia

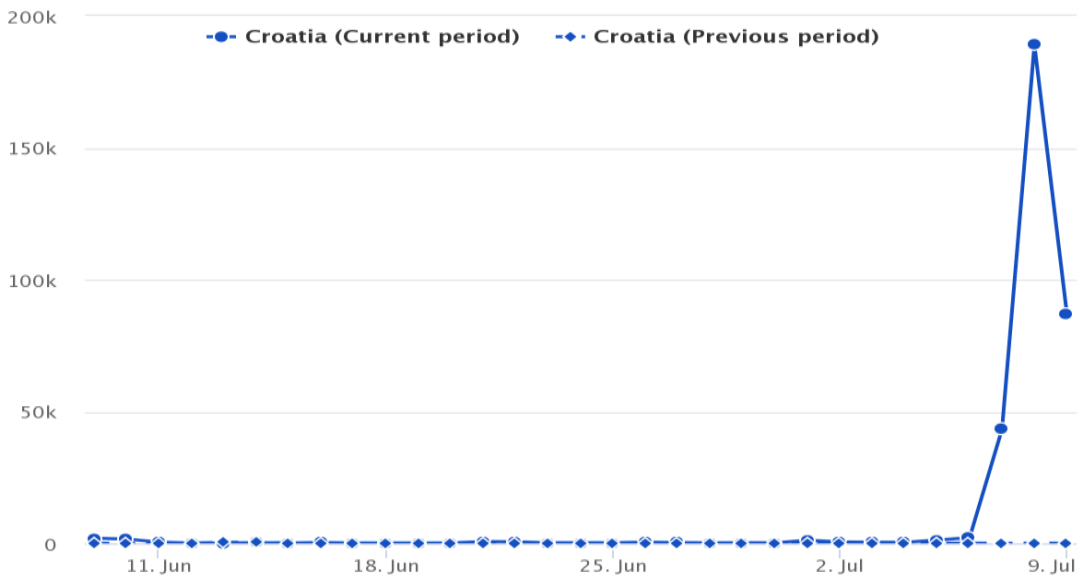

Source: Mediatoolkit

When we thought the numbers couldn't get any bigger, Croatia beat England, -resulting in more than 300,000 articles in the aftermath of the game Croatia made it to the final of the World Cup.

More than a billion people tuned in to watch the match between France and Croatia and over 3,4 billion people watched at least one minute of one match. ${ }^{1}$ More than 400,000 articles mentioning Croatia and over the course of the entire competition - more than a million. Between 7th and 15 July 2018 there has been a historical rise in the interest not only for the term Croatia, but also for the term "Visit Croatia”. „Mediatoolkit" measured a total number of 60 billion impressions on global websites for the term Croatia during the World Cup which is something brands can only dream about. As the Croatian football team played in the final, there were a whopping 1,5 million (1500 000) tweets about Croatia. It was the second most popular topic after the World Cup final. ${ }^{2}$

In the modern globalized world, a lot of space is opening for destinations which do not have a big population, but do have Luka Modrić, Goran Ivanišević, Janica and Ivica Kostelić, Croatian football, and many others frequently "dressed“ in Croatian flag, talked proudly about our country during major sporting events. These "national brand actors" can gain a comparative advantage with their positive image in the eyes of the global public.

\section{Conclusion}

It could generally be argued that image promotion require a long-term and consistent communication strategy implemented by a well national strategy and public diplomacy. Many European countries in transition whose reality changed dramatically (e.g. due to the fall of Communism) started seeking ways to present their national potential in order to develop their image promotion for both, the domestic market and export. ${ }^{3}$ Branding of nation presumes the definition of comprehensive strategy. Nation branding is concerned with image and promotion, and image promotion is identified as marketing communications techniques to promote the government as the initiator of branding. This definition takes into account that governments can not be branded per se, but governments and other public institutions can use the techniques of branding. The brand is meant to represent the nation's distinct and unique value among diverse international publics. Every country aims to drive some form of competitive advantage for their products through the country's brand image using tourism, culture and heritage, sport's achievements etc. Nation branding applies widely used marketing concepts to countries in the interest of enhancing their reputation. Foreign policy can also be the subject of branding public diplomacy. A key dimension of the

\footnotetext{
1 Mediatoolkit. https://www.mediatoolkit.com/blog/croatia-world-cup-media-analysis/

2 lbidem.

${ }^{3}$ Hall, D. (2004). Branding and national identity: the case of Central and Eastern Europe, in: Morgan, N.; Pritchard A. and Pride, R.

(Eds.). Destination Branding: Creating the Unique Destination Proposition. Oxford: Elsevier ButterworthHeinemann. 111-127.
} 
nation branding process is to assemble, in the early stages, a number of different groups of business and government parties. In order to be effective, the brand must be the conceptual product of all of its "owners" or "stakeholders". Politicians, states, companies, football, basketball, handball players, all these entities have an image and they are continually trying to shape brand image and trying to improve it, according to the vision of their identity to the global audience, which may be favourable or unfavourable.

\section{References:}

[1] Anderson, Benedict, Imagined communities: reflections on the origin and spread of nationalism, 1991, Verso, London.

[2] Aaker, D.A. (1992), Managing Brand Equity: Capitalising on the Value of a Brand Name, The Free Press, New York, NY.

[3] Aaker, Jennifer (1997), "Dimensions of Brand Personality", Journal of Marketing Research, 34, 347-356.

[4] Anholt, S. (2007). Competitive identity: The new brand management for nations, cities, and regions. New York, NY: Palgrave Macmillan.

[5] Arora R. \& Stoner Ch. (2009). A mixed method approach to understanding brand personality. Journal of Product \& Brand Management, 18(4), 272-283.

[6] Bannister J. P., Saunders, J. A., (1978), UK Consumers' Attitudes Toward Imports: The Measurement of National Stereotype Image. European Journal of Marketing, Vol. 12. No. 8. pp. 562-570.

[7] Ballantyne, R, Warren, A., Nobbs, K. (2005). The evolution of brand choice. Journal of Brand Management. 13(4/5):339-352.

[8] Brijs K., Bloemer, J., Kasper H., (2011), Country-Image Discourse Model: Unraveling Meaning, Structure, and Function of Country Images, in Journal of Business Research, Vol. 64. pp. 1259-1269.

[9] Chien-Hsiung, L. (2011). A study on the relations between the brand image and customer satisfaction in catering businesses. African Journal of Business Management Vol.5 (18), pp. 7732-7739.

[10] Ind, N., (1997), The Corporate Brand, Macmillan Press, London.

[11] Išoraite', M., ( 2018) Brand Image Development, ECOFORUM, Vol. 7, Issue 1(14).

[12] Olins, W (1999). 'Trading Identities - Why countries and companies are taking on each other's roles'. London: The Foreign Policy Centre.

[13] Denisa Adriana COTîRLEA ( 2015), Country image vs. Country brand: differences and similarities, Vol. 4, Special Issue 1.

[14] Dichter, E. (1985). What's in an image? Journal of Consumer Marketing, 2(1), 75-81.

[15] Dobni D (1990). In Search of Brand Image: A Foundation Analysis, Adv. Consum. Res., 17: 110-119.

[16] Đorđević, Bojan (2009) Corporate Strategic Branding: How Country and Corporate Brands Come Together; Economic Annals, No.177; P 59-88.

[17] Olins, W. (2002) 'Branding the Nation - the historical context', Brand Management

[18] 9(4-5): 241-248.

[19] Ham, P. van, (2002) 'Branding Territory: Inside the Wonderful Worlds of PR and IR Theory', Millennium 31(2): 249-269.

[20] Hall, D. (2004). Branding and national identity: the case of Central and Eastern Europe, in: Morgan, N.; Pritchard A. and Pride, R. (Eds.). Destination Branding: Creating the Unique Destination Proposition. Oxford: Elsevier ButterworthHeinemann. 111-127.

[21] Hawkins, D. I., Best, R. J., \& Coney, K. A. (2004). Consumer Behavior - Building Marketing Strategy. New York: McGraw-Hill.

[22] Herzog, H. (1963). Behavioral science concepts for analyzing the consumer. Marketing and the Behavioral Sciences, 76-86.

[23] Olins, W., (1999), "Trading Identities: Why Countries and Companies are Taking on Each Others Roles?", The Foreign Policy Center, London.

[24] Porter SS, Cindy C (1997). The Influence of Brand Recognition on Retail Store Image. J. Prod. Brand Manage., 6: 373-387.

[25] Robert AO, Patrick AKA (2009). The preference gap: Ghanaian consumers' attitudes toward local and imported products. Afr. J. Bus. Manage., 3(8): 350-357.

[26] Schiffman, L. G., \& Kanuk, L. L. (2010). Consumer Behavior. New Jersey: Pearson-Prentice Hall. 
[27] Kaneva, N. (2012). Branding Post-Communist Nations: Marketizing National Identities in the "New" Europe. Routledge.

[28] Kalieva, M., O. (2015). Development of Territory Brand Image: The Marketing Aspect. Review of European Studies; Vol. 7, No. 2; 23-27.

[29] Kapferer, J. N., (1994), Strategic Brand Management, The Free Press, New York.

[30] Keller, K.L. (1993), "Conceptualizing, Measuring, and Managing Customer-Based Brand Equity", Journal of Marketing, 57, 1-22.

[31] Kotler P., Haider D., Rein I., (1993), Marketing Places: Attracting Investment and Tourism to Cities, States and Nations, Free Press, 1993.

[32] Kunczik M., (1997), Images of nations and international public relations, New Jersey: Lawrence Erlbaum Associate, Publishers.

[33] Laqueur, W. (1994) 'Save Public Diplomacy - Broadcasting America's Message Matters' Foreign Affairs 73(5): 19-24.

[34] Lee ,J.,L., James, J., D., Kim, Y.,K. (2014). A Reconceptualization of Brand Image. International Journal of Business Administration Vol. 5, No. 4; 1-11.

[35] Magid, Julie M., Cox, Anthony D., Cox, D. S., Quantifying Brand Image: Empirical Evidence of Trademark Dilution. AMERICAN BUSINESS LAW JOURNAL, 43, 1; 1-42.

[36] Martin I. M., Eroglu S., (1993), Measuring a Multi-Dimensional Construct: Country Image, Journal of Business Research, Vol. 28. pp. 191-210.

[37] Malik ,M., E., Naeem , B., Munawar, M. (2012). Brand Image: Past, Present and Future. Journal of Basic and Applied Scientific Research. 2(12)13069-13075.

[38] Pujadi, B. (2010). Studi Tentang Pengaruh Citra Merek Terhadap Minat Beli Melaui Sikap Terhadap Merek. Semarang: Program Magister Manajemen Universitas Diponegoro.

[39] Szeles, P., (1998), A hírnév ereje. Image és arculat, Star PR Ügynökség, Budapest, pp. 81, 93, 94, 124, 138, in in Jenes Barbara, Theoretical and practical issues in measuring country image, 2012, Budapest.

[40] Smith, Anthony D., National identity" 1991, Penguin books.

[41] Szondi, G. (2008) 'Public Diplomacy and Nation Branding: Conceptual Similarities and Differences". Discussion papers in Diplomacy, Netherlands Institute of International Relations 'Clingendael'.

[42] Verlegh P. W. J., Steenkamp J-B., (1999), A Review and Meta-analysis of Country-of-Origin Research, in Journal of Economic Psychology. Vol. 20/1999. pp. 521-546.

[43] Vaxevanidou, M., (2017), Nation Rebranding in A Period of Crisis and the Role of Public Diplomacy: The Case Study of Greece. Journal of Media Critiques, Vol. 3, No. 11.

[44] Winarso, S. (2012). Pengaruh Nilai Pelanggan dan Citra Merek serta Hambatan Berpindah terhadap Kepuasan dan Loyalitas Pelanggan Maskapai Penerbangan Lion Air di Bandara Internasional Sepinggan Balikpapan. Surabaya: Program Pascasarjana Universitas Airlangga.

\section{On line reference}

Mediatoolkit. https://www.mediatoolkit.com/blog/croatia-world-cup-media-analysis/

The Anholt-GfK Nation Brands IndexSM (NBISM). < https://nation-brands.gfk.com/ > 